William M. Splinter MD FRCPC,* Juan Bass MD FRCSC $†$ Lydia Komocar RN*

\title{
Regional anaesthesia for hernia repair in children: local vs caudal anaesthesia
}

The purpose of this study was to compare the effect of local anaesthesia ( $L A)$ with that of caudal anaesthesia (CA) on postoperative care of children undergoing inguinal hernia repair. This was a randomized, single-blind investigation of 202 children aged 1-13 yr. Anaesthesia was induced with $\mathrm{N}_{2} \mathrm{O} / \mathrm{O}_{2}$ and halothane or propofol and maintained with $\mathrm{N}_{2} \mathrm{O} / \mathrm{O}_{2} /$ halothane. Local anaesthesia included ilioinguinal and iliohypogastric nerve block plus subcutaneous injection by the surgeon of up to $0.3 \mathrm{ml} \cdot \mathrm{kg}^{-1}$ bupivacaine $0.25 \%$ with $5 \mu \mathrm{g} \cdot \mathrm{kg}^{-1}$ adrenaline. The dose for caudal anaesthesia was $1 \mathrm{ml} \cdot \mathrm{kg}^{-1}$ up to $20 \mathrm{ml}$ bupivacaine $0.2 \%$ with $5 \mu \mathrm{g} \cdot \mathrm{kg}^{-1}$ adrenaline. Postoperative pain was assessed with $m C H E O P S$ in the anaesthesia recovery room, with postoperative usage of opioid and acetaminophen in the hospital, and with parental assessment of pain with a VAS. Vomiting, time to first ambulation and first urination were recorded. The postoperative pain scores and opioid usage were similar; however, the LA-group required more acetaminophen in the Day Care Surgical Unit. The incidence of vomiting and the times to first ambulation and first urination were similar. The LA-patients had a shorter recovery room stay (40 99 vs $45 \pm 15 \mathrm{~min}, P<0.02$ ). The postoperative stay was prolonged in the $C A$ group (176 \pm 32 vs $165 \pm 26$ min, $P=0.02$ ). We conclude that $L A$ and $C A$ have similar effects on postoperative care with only slight differences.

Cette étude vise à comparer les effets de l'anesthésie locale $(A L)$ avec ceux de l'anesthésie caudale $(A C)$ sur le suivi postopératoire

\section{Key words}

ANAESTHESIA: paediatric;

ANAESTHETICS, LOCAL: bupivacaine;

ANALGESIA: paediatrics;

ANALGESIA: postoperative;

ANALGESIC TECHNIQUES: caudal, local.

From the Departments of Anaesthesia* and Surgery $\dagger$, Children's Hospital of Eastern Ontario, and The University of Ottawa, Ottawa, Ontario, Canada.

Address correspondence to: $\mathrm{Dr}$. William Splinter, Department of Anaesthesia, Children's Hospital of Eastern Ontario, 401 Smyth Rd., Ottawa, Ontario, Canada, K1H 8L1. Accepted for publication 22nd November, 1994. d'enfants soumis à une cure de hernie inguinale. Cette étude randomisée et à l'aveugle porte sur 202 enfants âgés de 1 à 13 ans. L'anesthésie est induite au $\mathrm{N}_{2} \mathrm{O} / \mathrm{O}_{2}$ avec halothane ou au propofol et entretenue avec $\mathrm{N}_{2} \mathrm{O} / \mathrm{O}_{2} /$ halothane. L'anesthésie locale comprend le bloc ilioinguinal et iliohypogastrique avec injection maximale par le chirurgien de $0,3 \mathrm{ml} \cdot \mathrm{kg}^{-l}$ de buprvacä̈ne 0,25 avec $5 \mu \mathrm{g} \cdot \mathrm{kg}^{-l}$ d'adrénaline. Pour l'anesthésie caudale, on utilise $1 \mathrm{ml} \cdot \mathrm{kg}^{-1}$ jusqu’à un maximum de $20 \mathrm{ml}$ de bupivacaïne $0,2 \%$ avec $5 \mu \mathrm{g} \cdot \mathrm{kg}^{-1}$ d'adrénaline. La douleur postopératoire est évaluée par mCHEOPS à la salle de réveil, par la dose de morphinique et d'acétaminophène durant la séjour hospitalier et par l'évaluation sur l'EVA des parents. Les vomissements, le délai jusqu'à l'ambulation et la première miction sont enregistrés. Les scores sur l'échelle de la douleur et l'utilisation de morphinique sont identiques, mais le groupe $A L$ reçoit plus d'acétaminophène à l'unité de chirurgie d'un jour. Lincidence des vomissements et les délais à l'ambulation et à la première miction ne different pas. Les patients du groupe $A L$ demeurent moins longtemps à la salle de réveil ( $40 \pm 9$ vs $45 \pm 15 \mathrm{~min}, P<0,02$ ). Le séjour postopératoire est prolongé dans le groupe $A C$ (176 \pm 32 vs $165 \pm 26 \mathrm{~min}$, $P=0,02)$. Nous concluons que l'AL et l'AC, à l'exception de minimes différences, ont des effets identiques sur les soins postopératoires.

Management of pain after inguinal hernia repair in children may include intraoperative opioids, intraoperative regional anaesthesia, and postoperative analgesics, such as opioids and acetaminophen. Two regional techniques which decrease pain after inguinal hernia repair are caudal anaesthesia (CA) and local anaesthesia with ilioinguinal and iliohypogastric nerve block plus subcutaneous injection (LA). ${ }^{1-3}$ Both techniques are safe and are usually effective. ${ }^{4-8}$ Adverse events associated with these techniques include inadequate analgesia, retention of urine and delayed ambulation.

Several investigations have compared these two regional anaesthesia techniques. ${ }^{3,9-11}$ Generally, the investigations did not find differences between the groups, but the studies of 41-54 subjects lacked adequate power to detect clinically-important differences in failure rate. This 
study was designed to compare the two techniques and to test the hypothesis that local anaesthesia would have fewer side effects and provide superior analgesia to caudal anaesthesia.

\section{Methods}

With parental consent and Hospital Ethics Committee approval, 202 ASA class I-II children age 1-13 yr undergoing unilateral inguinal hernia repair were studied. Subjects were excluded if they had an allergy to a study drug or had received opioids or sedatives preoperatively. With standard monitors in place, general anaesthesia was induced with either $\mathrm{N}_{2} \mathrm{O}$ /halothane by mask or propofol $2.5 \mathrm{mg} \cdot \mathrm{kg}^{-1} i v$. Anaesthesia was maintained with $\mathrm{N}_{2} \mathrm{O} /$ halothane and subjects were given midazolam 50 $\mu \mathrm{g} \cdot \mathrm{kg}^{-1} \dot{\nu}$ intraoperatively. ${ }^{12}$ Subjects were randomly assigned to LA or CA using a random number table. The CA group ( $n=97)$ had CA performed with $1 \mathrm{ml} \cdot \mathrm{kg}^{-1}$ (up to $20 \mathrm{ml}$ ) bupivacaine $0.20 \%$ with $5 \mu \mathrm{g} \cdot \mathrm{kg}^{-1}$ adrenaline. Both the CA and LA group had a bandage placed over the caudal space. At the end of the hernia repair and before wound closure, up to $0.3 \mathrm{ml} \cdot \mathrm{kg}^{-1}$ of a solution containing $5 \mu \mathrm{g} \cdot \mathrm{kg}^{-1}$ adrenaline with bupivacaine $0.25 \%$ (LA group) or Normal Saline (CA group) was injected adjacent to the ilioinguinal and iliohypogastric nerves and into the subcutaneous tissue by the surgeon, who was unaware of the subject's group. The attending anaesthetist was not "blinded" because of ethical reasons wherein the caudal space was accessed only if a caudal block was done.

Pain was assessed in the recovery room q10min for $40 \mathrm{~min}$ by the research assistant (LK) with $\mathrm{mCHEOPS}^{13}$ (Table I). Pain scores greater than 6 were treated with morphine $50 \mu \mathrm{g} \cdot \mathrm{kg}^{-1} \mathrm{iv}$. The mCHEOPS is a valid and reliable method of assessing pain in children ${ }^{13}$ and has been used by others under similar situations. ${ }^{3}$ Unfortunately, the rated behaviours are child's cry, verbal responses, facial, limb and torso movements, which are not only associated with pain. Also, the original CHEOPS was developed primarily for children age of one to seven years. Additional recovery data were recorded up to five hours after completion of surgery. These included time to recover to an Aldrete ${ }^{14}$ score of 10 , incidence of vomiting, analgesic use (codeine $1 \mathrm{mg} \cdot \mathrm{kg}^{-1}$ po or $\mathrm{pr}$ and/ or acetaminophen $10 \mathrm{mg} \cdot \mathrm{kg}^{-1}$ po or pr), and time spent in recovery room, to first urination, and to first ambulation. The assessment of pain in the Day Care Surgical Unit (DCSU) was a simple chart review of analgesic administration. The DCSU nurses offered analgesics to patients based on their expectations of pain after hernia repair, their evaluation of the pain and after consultation with parents. Parents were contacted the day after surgery and were asked to rate their child's pain using a hor-
TABLE I Modified CHEOPS (mCHEOPS) ${ }^{12}$

\begin{tabular}{|c|c|c|c|}
\hline Score & 0 & $I$ & 2 \\
\hline Cry & No cry & Crying, moaning & Scream \\
\hline Facial & Smiling & Composed & Grimace \\
\hline Verbal & Positive & $\begin{array}{l}\text { None or other } \\
\text { complaint }\end{array}$ & Pain complaint \\
\hline Torso & Neutral & $\begin{array}{l}\text { Shifting, tense, } \\
\text { upright }\end{array}$ & Restrained \\
\hline Legs & Neutral & $\begin{array}{l}\text { Kick, squirm, } \\
\text { drawn-up }\end{array}$ & Restrained \\
\hline
\end{tabular}

TABLE II Patient characteristics

\begin{tabular}{lrllll}
\hline Group & $n$ & $\begin{array}{l}\text { Age } \\
(y r)\end{array}$ & $\begin{array}{l}\text { Weight } \\
(\mathrm{kg})\end{array}$ & $\begin{array}{l}\text { Percent iv } \\
\text { induction }\end{array}$ & $\begin{array}{l}\text { Anaesthesia } \\
\text { time (min) }\end{array}$ \\
\hline Caudal & 96 & $4.6 \pm 2.5$ & $18 \pm 6$ & $4 \%$ & $41 \pm 13$ \\
Local & 104 & $4.9 \pm 2.7$ & $19 \pm 7$ & $8 \%$ & $39 \pm 11$ \\
\hline
\end{tabular}

Mean \pm SD.

izontal linear analogue pain score with anchors of 0 (no pain) and 100 (worst pain imaginable). The parents had been instructed on the use of this scale on the day of surgery. Parents also reported any adverse outcomes, such as vomiting.

Data were analyzed with one-way ANOVA, Chi-square analysis, and Mann-Whitney $U$ test. Acceptable alpha error was 0.05 , the beta error for sample size calculation was 0.20 and the predicted difference between the groups' failure rates was $15 \%$. For the purpose of this investigation, blocks were considered to be inadequate if the patient required analgesics in the recovery room.

\section{Results}

One patient in each group was excluded from data analysis. A subject in the LA-group received intraoperative fentanyl and the caudal space was not accessed in one CA-group patient. The groups were similar with respect to demographic data, induction technique, and anaesthesia time (Table II).

In-hospital opioid use and pain scores in the PAR and at home were similar (Table III). The CA patients required less acetaminophen in the DCSU (Table III).

Twenty-three patients required morphine in the recovery room for pain. These patients were similarly distributed between the two groups with 11 in the CA group and 12 in the LA group (Table III). They were similar in age to the non-morphine-treated patients, $4.7 \pm 2.6$ vs $5.0 \pm 2.6 \mathrm{yr}$, mean $\pm \mathrm{SD}$. These 23 subjects did not fare as well as their contemporaries. They had a greater stay in recovery, $42 \pm 12$ vs $49 \pm 11 \min (P<0.02$, ANOVA), longer post-surgery hospital stay, $169 \pm 30$ vs $180 \pm 25 \min (P<0.05$, ANOVA $)$, increased incidence 
TABLE III Pain asssessment

\begin{tabular}{lllllll}
\hline \multirow{5}{*}{ Group } & Average & Pain score & \multicolumn{2}{l}{ Opioid use } & & $\begin{array}{l}\text { Analgesic in } \\
\text { first } 5 \mathrm{hr}\end{array}$ \\
\cline { 3 - 7 } & mCHEOPS & at home & Par & DCSU & Total & \\
\hline Caudal & $2.5 \pm 1.2$ & $5(0-70)$ & $11 \%$ & $20 \%$ & $30 \%$ & $57 \%$ \\
Local & $2.6 \pm 1.2$ & $5(0-80)$ & $12 \%$ & $21 \%$ & $28 \%$ & $78 \%^{*}$ \\
\hline
\end{tabular}

Mean $\pm \mathrm{SD}$ or median (range), ${ }^{*} P<0.01$, Chi-square analysis, $\mathrm{PAR}=$ recovery room, $\mathrm{DCSU}=$ day care

surgical unit, Analgesic $=$ opioid and $/$ or acetaminophen.

TABLE IV Recovery characteristics

\begin{tabular}{llllll}
\hline Group & $\begin{array}{l}\text { Time to } \\
\text { aldrete }=10 \\
(\min )\end{array}$ & $\begin{array}{l}\text { Time } \\
\text { in PAR } \\
(\mathrm{min})\end{array}$ & $\begin{array}{l}\text { Time to } \\
\text { discharge } \\
(\text { min })\end{array}$ & $\begin{array}{l}\text { Time to } \\
\text { ambulate } \\
(\mathrm{hr})\end{array}$ & $\begin{array}{l}\text { Time to } \\
\text { urinate } \\
(\mathrm{hr})\end{array}$ \\
\hline Caudal & $21 \pm 9$ & $45 \pm 15$ & $176 \pm 33$ & $1.5 \pm 1.3$ & $5.0 \pm 2.9$ \\
Local & $20 \pm 9$ & $40 \pm 9^{*}$ & $166 \pm 26^{*}$ & $1.2 \pm 1.0$ & $4.3 \pm 2.7$ \\
\hline
\end{tabular}

Mean $\pm \mathrm{SD}, * P<0.02$, ANOVA.

in vomiting, $29 \%$ vs $57 \%(P<0.001$, Chi-square), and greater parental assessment of pain after surgery, $2(0-80)$ vs $20(0-80)$, median (range) $(P<0.002$, Mann-Whitney $\mathrm{U}$ test).

The study groups required a similar time to reach an Aldrete recovery score of 10 (Table IV). The CA group had a longer recovery room stay and a prolonged inhospital postoperative stay. The time to ambulation and first urination was similar (Table IV). Four children in the CA group did not ambulate until four hours after surgery. One patient in each group did not urinate until the day after surgery. Four of the patients were scheduled postoperative admissions to hospital. None of the 196 remaining patients required unexpected admission to the hospital after surgery. Vomiting after surgery was comparable, $36 \%$ vs $29 \%$, in the CA and LA groups, respectively.

\section{Discussion}

The observation of a comparable effect on pain agrees with several investigators. ${ }^{3,9-11}$ Both groups had a low incidence of inadequate blocks in the recovery room, which is similar to the published 4-10\% failure rate. ${ }^{15,16}$ Inadequate blocks likely represent errors due to our circumstances, wherein most blocks are done by supervised trainees (surgery and anaesthesia). Higher success rates would be expected among experienced clinicians. ${ }^{8}$

The assessment of pain in children is difficult. A variety of methods of rating pain were used in this study and each has its merits. All the methods have validity and reliability, and were applied in a similar, blinded fashion to all ages of both groups. The methods used in this study were similar, but not identical with other comparable investigations. We had four patients with markedly delayed ambulation after CA, which is comparable with the $0-8 \%$ rate observed by others, ${ }^{16,17}$ and less than that noted by Dalens et al. (10\%), ${ }^{4}$ Fell et al. (14\%), ${ }^{9}$ and Yeoman et al. (31\%). ${ }^{18}$ The time to first postoperative micturition was similar to that observed by Fisher et al. ${ }^{15}$ As in this investigation, Schindler ${ }^{3}$ did not report any unscheduled admissions to hospital. The incidence of emesis is similar to the lower range of published rates of $20-70 \% .3,10$ The increased incidence of emesis associated with morphine usage is similar to that observed by Weinstein et al. ${ }^{19}$

The techniques used to perform the blocks have been described previously by others. There are no firmly established dosage schemes for either technique and each has reasonable alternatives. ${ }^{16,20}$ Caudal analgesia success rates may have been improved by increasing the bupivacaine concentration to $0.25 \%$ or increasing to a 1.25 $\mathrm{ml} \cdot \mathrm{kg}^{-1}$ volumes. The probable improved success rate would have to be carefully compared to an increased complication rate. ${ }^{10} \mathrm{~A} 1 \mathrm{ml} \cdot \mathrm{kg}^{-1}$ dose of bupivacaine is widely employed, simple and safe. ${ }^{9}$ The best method of local anaesthesia is unknown. A variety of techniques has been used and includes wound instillation, wound infiltration and local neural blockade of ilioinguinal, iliohypogastric and genitofemoral nerves. ${ }^{10}$ The optimal concentration of bupivacaine is not known and which combination of local blocks is optimal needs to be determined. For this study we chose a simple, effective technique, which we believe to be popular and clinically relevant. 
In conclusion, caudal anaesthesia and local anaesthesia appear to have similar effects on postoperative care after hernia repair in children.

\section{Acknowledgements}

We would like to thank our colleagues in the Departments of Anaesthesia and Surgery for their cooperation and support during this investigation.

\section{References}

1 Langer JC, Shandling $B$, Rosenberg $M$. Intraoperative bupivacaine during outpatient hernia repair in children: a randomized double blind trial. J Pediatr Surg 1987; 22 : 267-70.

2 Casey WF, Rice LJ, Hannallah RS, Broadman L, Norden $J M$, Guzzetta P. A comparison between bupivacaine instillation versus ilioinguinal/iliohypogastric nerve block for postoperative analgesia following inguinal herniorrhaphy in children. Anesthesiology 1990; 72: 637-9.

3 Schindler $M$, Swann $M$, Crawford $M$. A comparison of postoperative analgesia provided by wound infiltration or caudal analgesia. Anaesth Intensive Care 1991; 19: 46-9.

4 Dalens B, Hasnaoui A. Caudal anesthesia in pediatric surgery: success rate and adverse effects in 750 consecutive patients. Anesth Analg 1989; 68: 83-9.

5 Bertrix $L$, Foussat $C$, Moussa $M$, et al. Anesthésie caudale en chirurgie pédiatrique. Etude pharmacocinétique et intérêt clinique. Chirurgie Pédiatrique 1989; 30: 47-51.

6 Reid MF, Harris R, Philips PD, Barker I, Pereira NH, Bennett NR. Day-case herniotomy in children. A comparison of ilio-inguinal nerve block and wound infiltration for postoperative analgesia. Anaesthesia 1987; 42: 658-61.

7 Hinkle AJ. Percutaneous inguinal block for the outpatient management of post-herniorrhaphy pain in children. Anesthesiology 1987; 67: 411-3.

8 Veyckemans F, Van Obbergh LJ, Gouverneur JM. Lessons from 1100 pediatric caudal blocks in a teaching hospital. Reg Anesth 1992; 17: 119-25.

9 Fell $D$, Derrington $M C$, Taylor E, Wandless JG. Paediatric postoperative analgesia. A comparison between caudal block and wound infiltration of local anaesthetic. Anaesthesia 1988; 43: 107-10.

10 Cross GD, Barrett RF. Comparison of two regional techniques for postoperative analgesia in children following herniotomy and orchidopexy. Anaesthesia 1987; 42: 845-9.

11 Markham SJ, Tomlinson J, Hain WR. Ilioinguinal nerve block in children. A comparison with caudal block for intra and postoperative analgesia. Anaesthesia 1986; 41: 1098-103.

12 Splinter WM, MacNeill HB, Menard EA, Rhine EJ, Roberts $D W J$, Gould $H M$. Midazolam reduces vomiting after tonsillectomy in children. Can J Anaesth 1994; 42: 201-3.

13 Splinter $W M$, Semelhago $L C$, Chou $S$. The reliability and validity of a modified CHEOPS pain score. Anesth Analg 1994; 78: S413.

14 Aldrete JA, Kroulik D. A postanesthetic recovery score. Anesth Analg 1970; 49: 924-34.

15 Fisher $Q A$, McComiskey CM, Hill JL, et al. Postoperative volding interval and duration of analgesia following peripheral or caudal nerve blocks in children. Anesth Analg 1993; 76: 173-7.

16 Coad NR, Hain WR. Caudal anaesthesia for postoperative pain relief in children: a comparative trial of different regimens using plain bupivacaine. Ann R Coll Surg Engl 1989; 71: 245-8.

17 Vater $M$, Wandless J. Caudal or dorsal nerve block? A comparison of two local anaesthetic techniques for postoperative analgesia following day case circumcision. Acta Anaesthesiol Scand 1985; 29: 175-9.

18 Yeoman PM, Cooke R, Hain WR. Penile block for circumcision? A comparison with caudal blockade. Anaesthesia 1983; 38: 862-6.

19 Weinstein MS, Nicolson SC, Schreiner MS. A single dose of morphine sulfate increases the incidence of vomiting after outpatient inguinal surgery in children. Anesthesiology 1994; 81: 572-7.

20 Malviya S, Fear DW, Roy WL, Lerman J. Adequacy of caudal analgesia after penoscrotal and inguinal surgery using 0.5 or $1.0 \mathrm{ml} \cdot \mathrm{kg}^{-1}$ bupivacaine $0.125 \%$. Can J Anaesth 1992; 39: 449-53. 